\title{
A STUDY ON THE STRESS LEVEL OF PUBLIC SECTOR BANK EMPLOYEES WITH SPECIAL REFERENCE TO TIRUCHIRAPPALLI DISTRICT OF TAMIL NADU
}

\author{
Dr. M. Raja \\ Assistant Professor and Head, Department of Commerce, \\ Bharathidasan Unviersity Constituent College, Lalgudi, \\ Tamil Nadu, India. \\ E.mail: rajacommerce@gmail.com \\ Dr. M. Muthu Gopalakrishnan \\ Associate Professor, School of Business Studies and Social Sciences, \\ Christ (Deemed to be University), BGR Campus, Bengaluru, \\ Karnataka, India. \\ Email: muthulinks@yahoo.co.in

\section{Dr. R. Venkatamuni Reddy} \\ Professor, Department of Commmerce, Manipal Academy of Higher Education, \\ Manipal, Karnataka, India \\ Email: rvm.reddy@manipal.edu

\section{Prof. A. Nagaraj Subbarao} \\ Dean- Center for Executive Education \& Professor- Scms, \\ Dayananda sagar University, Innovation Campus, \\ Hosur Main road, Bangalore, India \\ Email: cap.nagaraj@gmail.com
}

\begin{abstract}
The modern working life has to do job related work speedily and without maintaining, considering or balance in physical and psychological status. Modern world has theme to address various occupations along with the situation of stress. Employee's stress is a normal part of working life and workers have to face and cope with it. The aim of this research study is to identify the job-related stress and it's causing factors in public sector banks through an empirical study of employees. The result of job-related stress is a deviation from the existing psychological and physical condition of employee's life. Based on this situation of employee's life is indicated as research problem of public sector banks. According to the findings of this research study, jobrelated stress factors of employees are correlated and influenced to their stress
\end{abstract}


significantly. Employees stress is an important issue to be addressed to improve the performance of public sector banks in India. The study revealed that the public sector banks have accountability to reduce the level of stress of their employees.

Key word: Employees Stress, Workload, Well-being and Organizational Commitment. Cite this Article: Dr. M. Raja, Dr. M. Muthu Gopalakrishnan, Dr. R. Venkatamuni Reddy, Prof. A. Nagaraj Subbarao, A Study on the Stress Level of Public Sector Bank Employees with Special Reference to Tiruchirappalli District of Tamil Nadu, Journal of Management, 6 (2), 2019, pp. 302-309.

http://www.iaeme.com/JOM/issues.asp?JType=JOM\&VType=6\&IType=2

\section{INTRODUCTION}

Stress is a normal part of human life and they have to face and cope with it and occupational stress is an ordinary part of working life. The effect of stress is confusion from the existing physical and psychological condition of workers life. Every individual has to suffer stress situations during life cycle. According to the existing condition someone has to cope with those changes, not only individuals, but the employees' society in the origination as well. Nelson et al. (2003) explained "stress is a significant matter in organizational behavior, in part due to the increase in competitive pressures that take a toll on workers and manager alike. One of the authors, Luthans (2002) described that stress is explain in negative conditions. The situations are thought to be sources by something bad. The situation of stress is viewed as inevitable results of employee functionality. With so many reasons effect to stress, actually it is difficult to explain the theme of stress. The term of stress was defined by so many researches. The first scientific investigation of stress is done by Hans Selye -1956, (Steve M Jex., 2002). Robbins (2005) has explained, 'stress is normally discussed in a harmful context and it also has a positive significance'. The job-related stress harmfully affects performance of the employees of an organization. It should not be a crisis of an organization alone. These organizations are evidently interrelated. Therefore, it should be observed that if the stress of an employee not only contributes the organization 'worker concerned' but also other institutions of a society as well. Ultimately, result of institute or society is goes to the economy or country. Few studies are made in India to cover the behavioral aspects of a human who is suffering from stress. The studies failed to measure the level of job related stress among public sector bank employees. The present study is one of attempts to fill the situation.

\section{STATEMENT OF THE PROBLEM}

There are several reasons of job-related grievances such as requirement of adequate time for the job, rush workloads, low compensation, unrealistic deadlines, institution environment difficulties, lack of clarity of role, emotion of underestimates and lack of clear policies related employee's duties. Even as external grounds of grievances are more challenging for managers to progressively manage, a worker who receives support from his working society is more likely to bind how this impacts his work position. Whatever the origins of job related stress, it is hinder the society and their teams and, in some cases, the wider working society. In this fact, as leaders managers can incorporate a significant part in reducing stress amongst their workers and reducing the result of its impact to the bank's profit. As pointed out, it seems that there are harms due to stress in the public sector banks. There are significant amount of research on stress of bank staff around the world. Hoffman (2006) revealed that, thousands of research studies have been carried out that identify various causes of stress. In India research studies in this field did not much effort to study stress concern as well as job stress in public sector banks. The present study is making an investigation regarding the major causes behind the situation. 


\section{LITERATURE REVIEW}

The literatures of the studies have been mentioned to provide the significance of this study and variables.

Job stress was hindered problem in the United Kingdom (Williams Stephen and Cooper Cary L, 1998). The outcome of this empirical study, measure with variables such as organizational satisfaction, job satisfaction, organizational security, organizational commitment, work environment, anxiety depression, worry, physical symptoms, resilience, workload and exhaustion.

Chandraiah, et al. (2003), investigated the effectiveness of job stress and job satisfaction among managers of special age groups in Calcutta City of India. The research study explained that, there was correlation between higher levels of job stress with job satisfaction and ages. According to the study, age is negatively correlated with job stress and age has positive interrelated with job satisfaction

Ronald and Burke (1976) found that the stress is considerably related to the job satisfaction and there are some occupations; reporting worse than average scores for each of the factors named health - psychological and physical, as well as satisfaction with happiness.

According to Wen- Hsien Ho, et al., there are correlations, job rotation, workload, occupational satisfaction and organizational commitments with sources of stress (2009).

The study (Rashmi S. and Gole 2008) found that stress has relationship with job performance and job satisfaction. Further the study concluded, higher stress is correlated to lower performance and higher job satisfaction is linked with higher performance.

\section{RESEARCH QUESTIONS}

The research questions as follows:

- What is the level of stress the employees of private sector commercial banks in Tiruchirappalli distruct of Tamil Nadu?

- What are the factors that importance job stress the employees of private sector commercial banks in Tiruchirappalli distruct of Tamil Nadu?

\section{OBJECTIVES}

The objectives of the study are;

- To find out the contribution level of factors of job stress among employees in public sector banks.

- To identify the relationships between the various dimensions of job stress related variables.

- To provide a suggestion to minimize occupational stress among employees in public sector banks.

\section{Hypotheses}

The hypotheses as follows:

$\mathbf{H}_{1}=$ There is a positive relationship between the degree of workload and the employees stress related variables in public sector banks.

$\mathbf{H}_{2}=$ There is a positive relationship between the degree of dissatisfaction with the degree of organizational commitment of employee's in public sector banks. 
A Study on the Stress Level of Public Sector Bank Employees with Special Reference to Tiruchirappalli District of Tamil Nadu

\section{METHODOLOGY}

\subsection{Sample}

The population for the present study consists of 100 public sector commercial bank employees in Tiruchirappalli district which are randomly selected. The sample of the presesent study covers the employees of 5 public sector bank branches (State Bank of India. Canara Bank, Indian Bank, Punjab National Bank, Indian Overseas Bank) Tiruchirappalli city.

\subsection{Statistical Tools}

The variables were analyzed by the Multiple Regression, ANOVA and the Karl person's coefficient of correlation in tune with the objective of the study. All the analysis was carried out using the software SPPS version 17. And also, the Karl person's coefficient of correlation was applied in this study for testing the hypothesis.

\subsection{Stress Levels - Variables wise}

Table $\mathbf{- 1}$ describes the results of multiple regression analysis of the sample respondents in terms of $\mathrm{R}$ (Multiple Correlation Coefficient), $\mathrm{R}^{2}$ (coefficient determination) and the incremental value of $\mathrm{R}^{2}$ (Level of stress).

Table 1 Result of Multiple Regression Analysis

\begin{tabular}{|l|l|l|l|}
\hline Variables & $\mathrm{R}$ & $\mathrm{R}^{2}$ & $\begin{array}{l}\text { Incremental } \\
\text { value } \mathrm{R}^{2}\end{array}$ \\
\hline Workload & 0.687 & 0.471 & 0.471 \\
\hline Organizational Commitment & 0.837 & 0.700 & 0.229 \\
\hline Dissatisfaction & 0.920 & 0.846 & 0.146 \\
\hline Work Environment & 0.990 & 0.980 & 0.134 \\
\hline Well-being & 1.000 & 1.000 & 0.020 \\
\hline
\end{tabular}

Source Primary Data

It is found from the above Table that among the five factors, the Workload related stress explains levels of contribution $47.1 \%$ of the total stress. The job Organizational Commitment related stress accounts (level of contribution) for 22.9\%. The Dissatisfaction related stress explains $14.6 \%$, Work Environment related stress accounts for 13.4\% and Well-being related stress $2.0 \%$ of the total stress. It is inferred that Dissatisfaction related stress gets $47.1 \%$, as higher level while occupational related stress. It is also noted from the above Table that nearly $47.1 \%$ is recorded in the Workload related stress among employees in public sector banks of Tiruchirappalli district of Tamil nadu.

\subsection{Significance of the Variables}

Table - 2 express the results of ANOVA analysis in terms of source of factors (variables), Sample Group, Sum of Squares, degree of freedom, mean squares, F ratio, p value and their significance of the respondents on job stress.

Table 2 ANOVA Table for Job Stress

\begin{tabular}{|l|l|c|c|c|c|c|}
\hline \multicolumn{1}{|c|}{ Variables } & \multicolumn{1}{|c|}{ Sample Group } & $\begin{array}{c}\text { Sum of } \\
\text { Squares }\end{array}$ & df & $\begin{array}{c}\text { Mean } \\
\text { Squares }\end{array}$ & F & $\begin{array}{c}\text { Sig./ not } \\
\text { sig. }\end{array}$ \\
\hline Workload & Between Group & 18.643 & 3 & 3.125 & 3.637 & .058 \\
& Within Group & 452.123 & 97 & .884 & & \\
& Total & 470.766 & 100 & & & \\
\hline
\end{tabular}


Dr. M. Raja, Dr. M. Muthu Gopalakrishnan, Dr. R. Venkatamuni Reddy, Prof. A. Nagaraj Subbarao

\begin{tabular}{|l|l|c|c|c|c|c|}
\hline \multicolumn{1}{|c|}{ Variables } & \multicolumn{1}{|c|}{ Sample Group } & $\begin{array}{c}\text { Sum of } \\
\text { Squares }\end{array}$ & df & $\begin{array}{c}\text { Mean } \\
\text { Squares }\end{array}$ & F & $\begin{array}{c}\text { Sig./ not } \\
\text { sig. }\end{array}$ \\
\hline Organizational & Between Group & 12.252 & 3 & 2.396 & 3.406 & .053 \\
Commitment & Within Group & 216.700 & 97 & .703 & & \\
& Total & 228.952 & 100 & & & \\
\hline \multirow{3}{*}{ Dissatisfaction } & Between Group & 7.377 & 3 & 1.341 & 2.867 & .052 \\
& Within Group & 138.277 & 97 & .328 & & \\
& Total & 145.654 & 100 & & & \\
\hline Work & Between Group & 7.244 & 3 & 1.101 & 2.763 & .051 \\
Environment & Within Group & 126.288 & 97 & .371 & & \\
& Total & 133.532 & 100 & & & \\
\hline Well- being & Between Group & 5.876 & 3 & .701 & 2.689 & .052 \\
& Within Group & 14.113 & 97 & .201 & & \\
& Total & 19.989 & 100 & & & \\
\hline
\end{tabular}

Source: Primary Data

From the above table it is found that the dissatisfaction $(\mathrm{F}=3.637, \mathrm{P}=.058)$ variable of job stress of employees in public sector banks is statistically significant at the $5 \%$ level. It is understood that, the job stress of employees in public sector banks was significant with the Workload. It is shown that the organizational commitment $(\mathrm{F}=3.406, \mathrm{P}=.053)$ variable of job stress of employs in public sector banks is statistically significant at the 5\% level. It is clear that, the job stress of employees in public sector banks was significant with the organizational commitment.

And also, other three variables; dissatisfaction, work environment and well-being are $(\mathrm{F}=$ $2.867, \mathrm{P}=.052)(\mathrm{F}=2.763, \mathrm{P}=.051)(\mathrm{F}=2.689, \mathrm{P}=.052)$ respectively, the variables of job stress of employees in public sector banks are statistically significant at the $5 \%$ level. The job stress of employees in private sector commercial banks is significant with the above variables.

\subsection{Correlation of Variables}

Table -3 reveals the results of inter correlation analysis between the different variables of stress the employees working in public sector banks in Tiruchirappalli district of Tamil nadu in the form of the correlation matrix, Further; the significance of the correlation is also indicated.

Table 3 Correlation of Variables

\begin{tabular}{|c|c|c|c|c|c|}
\hline Variables of Stress & 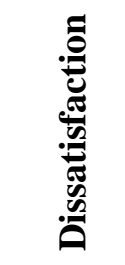 & 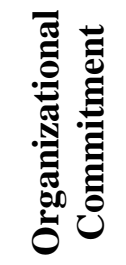 & 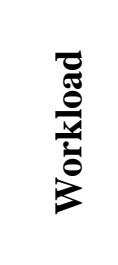 & 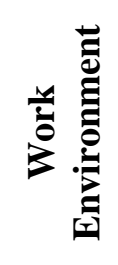 & 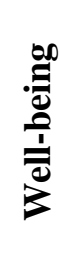 \\
\hline Workload & 1 & & & & \\
\hline Organizational Commitment & $0.720 *$ & 1 & & & \\
\hline Dissatisfaction & $0.585^{*}$ & $0.760^{*}$ & 1 & & \\
\hline Work Environment & 0.387 & 0.506 & $0.606^{*}$ & 1 & \\
\hline Well-being & $0.444 *$ & $0.668^{*}$ & $0.676^{*}$ & $0.682 *$ & 1 \\
\hline
\end{tabular}

*- Significant at $5 \%$ level,

Source Primary Data

The Table reveals that there exists a significant inter correlation between the different variables of stress the employees in public sector banks of Tiruchirappalli district of Tamil 
A Study on the Stress Level of Public Sector Bank Employees with Special Reference to Tiruchirappalli District of Tamil Nadu

nadu. It is inferred that there exists a significant inter correlation between the various stress related factors of employees in public sector banks of Tiruchirappalli district of Tamil nadu.

\subsection{Testing -Hypotheses}

$\mathbf{H}_{\mathbf{1}}=$ There is a positive relationship between the degree of workload and the employee's stress related variables in public sector banks of Tiruchirappalli district of Tamil nadu.

It is found from the above Table that the hypothesis 1, "There is a positive relationship between the degree of Workload and the employee's stress related variables in public sector banks of Tiruchirappalli district of Tamil nadu." is accepted. The correlation was positive and significant in all the cases of Workload (four cases in Workload), Dissatisfaction $\left(0.585^{*}\right)$, Organizational Commitment $\left(0.760^{*}\right)$, Work Environment $\left(0.606^{*}\right)$ and Well-being $\left(0.676^{*}\right)$. The above hypothesis is accepted since correlation value was positive and significant.

$\mathbf{H}_{2}=$ There is a positive relationship between the degree of dissatisfaction with the degree of organizational commitment, employee's in public sector banks of Tiruchirappalli district of Tamil nadu.

According to Table, hypothesis 2, "There is a positive relationship between the degrees of dissatisfaction with the degree of organizational commitment, employees in public sector banks of Tiruchirappalli district of Tamil nadu." is accepted. The correlation was positive and significant in the cases of, Dissatisfaction with Organizational Commitment $\left(0.720^{*}\right)$. The above hypothesis is accepted since correlation was positive and significant.

\section{FINDING AND DISCUSSION}

The study was conducted the employees in public sector banks of Tiruchirappalli district of Tamil nadu. The findings and discussion of the study are as follows.

- The result of analysis that there exists significant and positive inter correlation between the various stress related factors of the employees in public sector banks of Tiruchirappalli district of Tamil nadu.

- The analysis of this study shows that there exists the significant difference between all the factors of the job related stress in the employees in public sector banks of Tiruchirappalli district of Tamil nadu. Hence, the level of stress is significantly more among employees.

- It is inferred that the dissatisfaction had significant influence on job stress of employees in public sector banks.

- The organizational commitment of staff about banks was another reason for increased level of stress.

- And the study found that the workload was an important reason for increased level of stress. The correlation was positive and significant in all the cases of workload stress related factors of the employees in public sector banks of Tiruchirappalli district of Tamil nadu.

\section{SUGGESTIONS OF THE STUDY}

The following suggestion is provided to reduce the stress of employees in public sector banks of Tiruchirappalli district of Tamil nadu.

Detailed research by the government of India and management of public sector banks should be conducted periodically to study the situation of occupational stress among employees of public sector banks. The stress management is an important issue to be addressed to maximize the performance of public sector banks in Tamil nadu by minimizing the level of stress of employees. 


\section{CONCLUSION}

The analysis was revealed that Dissatisfaction, Organizational Commitment, Workload, Work Environment and Well-being, were significantly influenced on the occupational stress of rmployees. The majority of factors were interrelated. It can be exposed that majority of factors are correlated with job stress. And stress related factors have significantly influenced stress. Finally, from overall analysis, employees in public sector banks of Tiruchirappalli district of Tamil nadu were suffering from stress. The study recognized that the public sector banks have accountability to reduce the level of stress of employees. Further, detailed research by government of India and management of public sector banks should be conducted periodically to study the issue of occupational stress among employees in public sector banks. Stress management is an important issue to be addressed to maximize the performance of public sector banks in India by minimizing the level of job stress of employees.

\section{REFERENCES}

[1] Altbach, P.G, 'The International Academic Profession'. (Ed). Princeton N.J.: Carnegie Foundation for the Advancement of Teaching, London, 1996

[2] Central Bank of Sri Lanka, 'Economic and Social Statistics of Sri Lanka', Colombo, 2012

[3] Chandraiah K, Agarwal S C, Marimuthu P and Manoharan N, “ Occupational Stress and job Satisfaction among managers" Indian Journal of Occupational and Environmental Medicine, Vol.7, No.2, 2003, PP6-11

[4] Cooper C.L.and Catwright S, Healthy mind, healthy organization: A proactive approach to occupational stress. Human Relation. Australia. 47 (4), 1994, Pp. 455- 471.

[5] Hanson, P, The Joy of Stress. Revised 2nd Edition. Islington, Ontario: Hanson, 1986

[6] Hoffman Richard, 'An Assessment of the level of stress among beginning counselor education graduate students, students beginning the counseling practicum and students graduating from their program of studies'. Duquesne University. Pittsburgh. PA. USA, 2006

[7] Jex, S. M, Organizational Psychology. John Wiley and Sons, Inc. New York, 2006, pp 179207.

[8] John G, Occupational stress and well- being at work. In P. Cotton (Ed.) Psychological health in the workplace. Carlton, Vic: Australian Psychological Society, 1998

[9] Kumara sajjan, and Jejurkar Krupa, " Study of Stress level in Occupational Therapy Students during their Academic Curriculum" The Indian Journal of Occupational Therapy. Vol.XXXVII, no. 1, 2005, PP. 11-14, http://www.indmedica.com

[10] Lovelace Richard Terry (1988- 2004), 'Stress \& Moods Mastery' Online document: www.trouthforhealthyliving.org/legal

[11] Luthans Fred, 'Organizational Behavior', McGraw-Hill, New York, NY10020, America, 2002, Pp. 395- 422.

[12] Mohanty R.P, Managing Human Capital. Excel Books, New Delhi, 2006, pp 121-126.

[13] Nelson Debra L. and Quick James Campbell (2003) 'Organizational Behavior', Thomson South -Western, Ohio 45040, 2003, Pp 216- 241

[14] Oi-Ling Siu, 'Occupational Stress among School teachers: A Review of Research Findings Relevant to Policy Formation' Education Journal, Chinese University of Hong Kong, 1996

[15] Rashmi S. and Gole, "Effect of Job Stress and Job Satisfaction on Performance; An empirical study". AIMS International Journal of Management. Vol.3, No.2, 2008, PP.237 246 
A Study on the Stress Level of Public Sector Bank Employees with Special Reference to Tiruchirappalli District of Tamil Nadu

[16] Robbins Stephen P, 'Organizational Behavior', F.I.E. Patparganj, Delhi 110092, India, 2005, Pp. 576 - 586.

[17] Ronald and Burke, R.J, 'Occupational Stress and Job Satisfaction', Journal of Social Psychology, Vol. 100, 1976, Pp. 235 - 244

[18] Steve M. Jex, 'Organizational psychology', John Wiley \& Sons (Asia) Pte Ltd, 2 Clementi Loop, Sigapore 129809, 2002

[19] Wen- Hsien Ho, Ching Sheng Chang S., Ying- Ling Shin and Rong - Da Liang, "Effect of Job Rotation and Role Stress among Nurses on Job Satisfaction and Organizational Commitment". BMC Health Service Research. Vol.9, No.8, 2009

[20] Williams Stephen and Cooper Cary L, 'Measuring Occupational Stress: Development of the Pressure Management Indicator' Journal of Occupational Health Psychology, American Psychological Association. Washington Vol. 3, No. 4, 1998, Pp. 306-321

[21] Woods Antoinette Petrazzi, 'The Relationship of Burnout to Contextual Work Factors for Rural Community Mental Health Counselors'. Executive Doctoral Program in Counselor Education and Supervision School of Education, Duquesne University, Pittsburgh, PA, USA, 2005

[22] www.cbsl.lk, 25.01.2013

[23] www.peoplesbank.lk, 31.01.2013

[24] www.unl.edu/stress/mgmt/concept.html

[25] www.web.boc.lk, 31.01.2013, 